\title{
ANALISIS PENURUNAN MUKA TANAH DKI JAKARTA DENGAN METODE DIFFERENTIAL INTERFEROMETRY SYNTHETIC APERTURE RADAR (DINSAR)
}

\author{
CYNTIA*, I PUTU PUDJA \\ Prodi Geofisika, \\ Sekolah Tinggi Meteorologi Klimatologi dan Geofisika \\ Jl. Perhubungan I No. 5, Pondok Betung, Pondok Aren, Tangerang Selatan 15221 \\ *email : cyntia.almasah7733@gmail.com
}

\begin{abstract}
Abstrak.Penurunan muka tanah di DKI Jakarta dipengaruhi oleh beberapa faktorutama, antara lain jumlah bangunan yang meningkatkan beban permukaan tanah, masih banyak masyarakatnya yang memanfaatkan sumber air tanah sebagai sumber pokok air bersih, serta struktur geologi yang didominasi dengan aluvial. Sehingga penurunan muka tanah di DKI Jakarta relatif terus-menerus terjadi. Untuk mengetahui penurunan muka tanah ini digunakan metode penginderaan jarak jauh, yakni metode DifferentialInterferometry Synthetic Apertur Radar (DInSAR) yang memanfaatkan citra satelitdata radar (SAR Sentinel-1A) pada tahun 2016 dan 2017. Hasilnya menunjukkan bahwa nilai penurunan rata-rata di kota administrasi DKI Jakarta pada tahun 2016 cukup signifikan jika dibandingkan pada tahun 2017.
\end{abstract}

Kata kunci : penurunan muka tanah, DKI Jakarta, Metode DInSAR, Sentinel-1A

\begin{abstract}
Land subsidence in Jakarta influenced by several key factors, including thenumber of buildings that increase the burden of the ground, there are still many people who use groundwater sources as the principal source of clean water, as well as the geological structure is dominated by alluvial. So that the land subsidence in Jakarta relatively constantly occur. To find this use of land subsidence remote sensing methods, namely methods Differential Interferometry Synthetic Aperture Radar (DInSAR) that utilizes satellite images of data radar (SAR Sentinel-1A) in 2016 and 2017. The result shows that the average subsidence in DKI Jakarta in 2016 is significant when compared to 2017.
\end{abstract}

Keywords : subsidence, DKI Jakarta, DInSAR method, Sentinel-1A

\section{Pendahuluan}

DKI Jakarta sebagai kota metropolitan Indonesia dengan hamparan tanah seluas $662,33 \mathrm{~km}^{2}$ ditinggali sekitar 10.177.924 jiwa (BPS, 2015) padahal secara kuantitatif jumlah ini merupakan $4 \%$ dari total penduduk Indonesia. Berdasarkan penyebabnya, terdapat tiga faktor utama yang dapat mempercepat penurunan muka tanah, antara lain: faktor alami (geologi); faktor pengambilan air tanah; dan faktor massa bangunan. Faktor pengambilan air tanah yang berlebihan ini diyakini sebagai salah satu faktor utama yang mengakibatkan penurunan muka tanah. Hal ini terjadi karena masih banyak warga DKI Jakarta yang belum beralih menggunakan air PAM RT (Pengelolaan air minum rumah tangga). 
Oleh karena itu dilakukan penelitian lanjutan mengenai penurunan muka tanah untuk mengetahui nilai rentang terbaru di DKI Jakarta. Salah satu metode berbasis penginderaan jarak jauh digunakan untuk menganalisis penurunan muka tanahyakniDifferential Interferometric Synthetic Aperture Radar (DInSAR) menggunakan citra satelit Sentinel-1A pada tahun 2016 dan 2017. Hasil DInSAR berupa DEM (Digital Elevation Model) yang digunakan untuk membuat peta penurunan muka tanah.

Dalam penelitian ini diharapkan dapat menggambarkan dan memberikan informasi penting mengenai perubahan penurunan muka tanah di DKI Jakarta. Kemudian dapat dijadikan sebagai acuan bagi Pemertintah setempat untuk dapat ditindaklanjuti.

\section{Metode Penelitian}

A. Daerah Penelitian

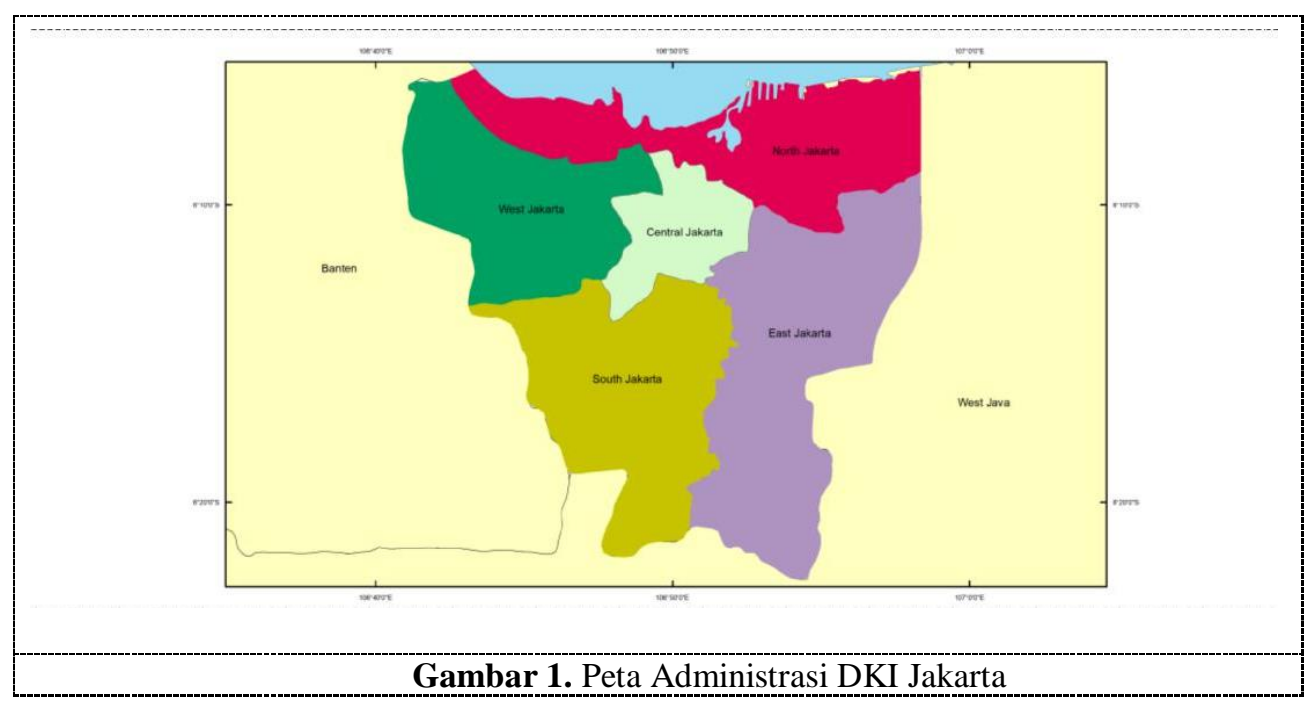

Daerah penelitian di DKI Jakarta (Gambar 1), ibukota Indonesia dengan garis bujur dan garis lintang pada $106^{\circ} 22^{\prime} 422^{\prime}$ BT sampai $106^{\circ} 58^{\prime} 18^{\prime \prime}$ BT dan $5^{\circ} 19$ '12" LS hingga $6^{\circ} 23^{\prime}$ 54" LS. Provinsi ini memiliki lima kota administrasi yaitu Jakarta Utara, Jakarta Barat, Jakarta Pusat, Jakarta Timur, dan Jakarta Selatan yang dapat dilihat pada Gambar 1.

\section{B. Metode DInSAR}

Differential Interferometric Synthetic Aperture Radar (DInSAR) adalahmetode pencitraan radar ke samping dengan memanfaatkan perbedaan fasa dua atau lebih citra SAR dengan akuisisi yang berbeda dalam pengolahannya untuk mendapatkan topografi dan deformasi (Akbar dkk., 2015).

Francis dkk. (1996) menuliskan bahwa teknik DInSAR pada dasarnya menggunakan dua citra SAR untuk mengidentifikasi perubahan spasial suatu daerah yang memanfaatkan koheren dalam pengukuran fase interferometrik dari permukaan yang sama. Hasil dari perbedaan fase menghasilkan jenis citra baru 
yang disebut interferogram. Interferogram akan menunjukkan apakah wilayah yang diteliti tersebut mengalami penurunan muka tanah atau kenaikan muka tanah.

Fase interferometric $(\Delta \varphi)$ yang dihasilkan oleh InSAR terdiri dari lima kontribusi sinyal fase: $\Delta \varphi_{\text {flat }}$ adalah fasa akibat pengaruh topografi, $\Delta \varphi_{\text {elevasi }}$ adalah fasa akibat pengaruh ketinggian, $\Delta \varphi_{\text {deformasi }}$ adalah fase akibat adanya perubahan di permukaan (deformasi), $\Delta \varphi_{\text {atmosfer }}$ adalah fasa akibat pengaruh atmosfer, dan $\Delta \varphi_{\text {noise }}$ adalah fasa akibatnoise. Berikut rumusan fase yang digunakan dalammetode DInSAR:

$$
\begin{aligned}
\Delta \varphi= & \Delta \varphi_{\text {flat }}(a)+\Delta \varphi_{\text {elevasi }}(b)+\Delta \varphi_{\text {deformasi }}(c)+\Delta \varphi_{\text {atmosfer }}+\Delta \varphi_{\text {noise }} \\
\text { a. } & -\frac{4 \pi}{\lambda} \frac{B_{n}}{R \tan \theta} \\
b . & -\frac{\Delta q}{\sin \theta} \cdot \frac{B_{n}}{R} \cdot \frac{4 \pi}{\lambda} \\
c . & +\frac{4 \pi}{\lambda} d
\end{aligned}
$$

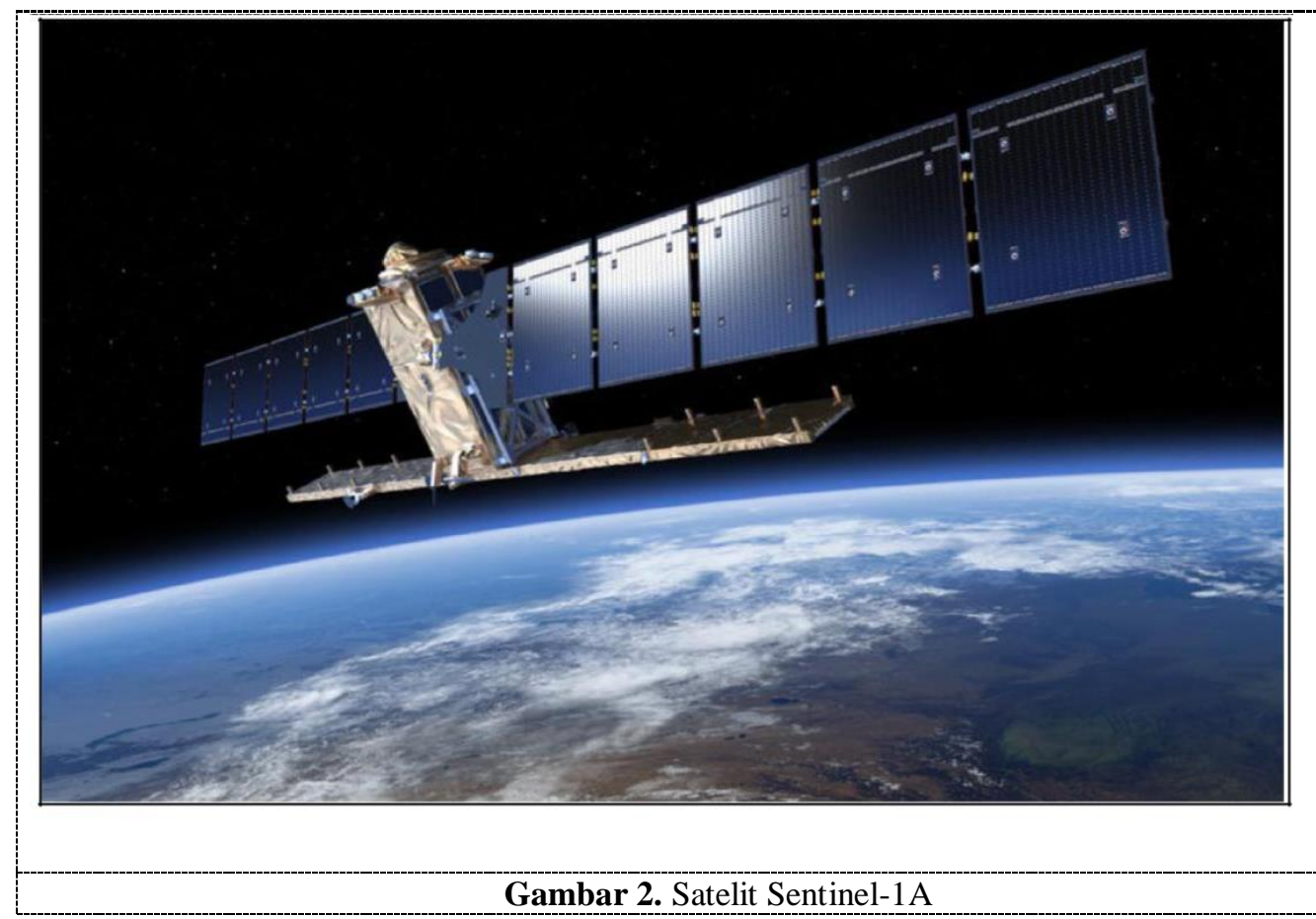

Sentinel-1A (Gambar 2) adalah satelit pencitraan radar Eropa yang diluncurkan pada tahun 2014. Ini adalah satelit Sentinel-1 pertama yang diluncurkan sebagai bagian dari program Copernicus Uni Eropa. Satelit ini membawa Radar 
Aperture C-band dengan frekuensi $5,405 \mathrm{GHz}$ dan melakukan pencitraan pada daerah yang sama dengan selang waktu 12 hari di ketinggian orbit $693 \mathrm{~km}$ dan pada inklinasi $98,18^{\circ}$. Gelombang C-band paling berguna untuk hutan yang tidak lebat dan kanopi yang jarang, juga telah digunakan untuk memetakan luas genangan rawa di dataran rendah di Roanoke. (Chavez dkk., 2009). Satelit ini dapat melacak dalam segala aspek lingkungan, mulai dari mendeteksi dan melacak tumpahan minyak dan pemetaan es laut ke gerakan pemantauan di permukaan tanah dan pemetaan perubahan cara penggunaan lahan, serta perubahan deformasi lahan (subsidensi).

Produk data yang dihasilkan oleh satelit Sentinel-1A terbagi menjadi empat mode akuisisi (resolusi spasial). Berikut dijelaskan dalam Tabel 1:

Tabel 1. Produk resolusi spasial

\begin{tabular}{ll}
\hline \multicolumn{1}{c}{ Jenis Resolusi Spasial } & Besar Resolusi Spasial \\
\hline Strip Map $($ SM) mode: $80 \mathrm{~km}$ swath & $5 \mathrm{~m} \times 5 \mathrm{~m}$ \\
Interferometric Wide $(I W)$ swath: & \\
250 km swath & $5 \mathrm{~m} \times 20 \mathrm{~m}$ \\
Extra Wide $(E W)$ swath mode: 400 & \\
km swath & $25 \mathrm{~m} \times 100 \mathrm{~m}$ \\
Wave $(W V)$ mode: $20 \mathrm{~km} \times 20 \mathrm{~km}$ & $5 \mathrm{~m} \times 20 \mathrm{~m}$ \\
\hline
\end{tabular}

Adapun produk yang tersedia pada Sentinel-1A adalah polarisasi VV dan polarisasi VH dengan lintasan satelit ascending maupun descending. Data yang tersedia juga bervariasi dan berbeda karakter. Berikut adalah produk data dan karakteristik citra Sentinel-1A, dijelaskan dalam Tabel 2 :

Tabel 2. Produk karakteristik Sentinel-1A

\begin{tabular}{lcl}
\hline \multicolumn{1}{c}{ Produk Sentinel-1A } & $\begin{array}{c}\text { Ukuran } \\
\text { Data }\end{array}$ & \multicolumn{1}{c}{ Karakteristik } \\
\hline Level-0 Raw Data & 1 GB & Data mentah \\
Level-1 SLC & $8 \mathrm{~GB}$ & $\begin{array}{l}\text { Terdiri dari amplitudo dan fasa } \\
\text { Level-1 GRD }\end{array}$ \\
& $1 \mathrm{~GB}$ & $\begin{array}{l}\text { Terdiri dari amplitudo dengan } \\
\text { intensitas multilook } \\
\end{array}$ \\
& & $\begin{array}{l}\text { Terdapat parameter arus, gelombang, } \\
\text { arah angin }\end{array}$ \\
\hline
\end{tabular}

D. Data Penelitian

Data menggunakan radar Sentinel-1A pada tahun 2016 dan 2017 yang diunduh di Alaska Satellite Facility (ASF). Dijelaskan dalam Tabel 3 dan Tabel 4.

Tabel 3. Citra SAR yang digunakan tahun 2016 dan 2017

\begin{tabular}{cccccc}
\hline Data & Tanggal Akuisisi & Level & Mode Akuisisi & Polarisasi & Sudut Pandang \\
Tahun & 23 Januari 2016 & 1.0 & IW & VV & Ascending \\
2016 & 24 Desember 2016 & 1.0 & IW & VV & Ascending \\
2016 & 17 Januari 2017 & 1.0 & IW & VV & Ascending \\
2017 & 7 Desember 2017 & 1.0 & IW & VV & Ascending \\
\hline
\end{tabular}


Tabel 4. Citra SAR yang digunakan tahun 2016 dan 2017

\begin{tabular}{rccc}
\hline $\begin{array}{r}\text { Tanggal } \\
\text { Akuisisi }\end{array}$ & Lintasan & $\begin{array}{c}\text { Baseline } \\
\text { Perpendicular }(\mathbf{m})\end{array}$ & $\begin{array}{c}\text { Baseline Temporal } \\
\text { (hari) }\end{array}$ \\
\hline $24 / 12 / 2016$ & 98 & 0,00 & 0 \\
$23 / 01 / 2016$ & 98 & 14,07 & 336 \\
$07 / 12 / 2016$ & 98 & 0,00 & 0 \\
$17 / 01 / 2016$ & 98 & $-54,76$ & 334 \\
\hline
\end{tabular}

E. Metodologi Penelitian

Data yang telah diperoleh, diproses dalam perangkat lunak SNAP yang dapat dioperasikan pada Windows dan Linux, dan perangkat lunak SNAPHU yang hanya bisa dioperasikan di Linux. Hasil akhirnya adalah Digital Elevation Model (DEM) yang digunakan untuk membuat peta penurunan tanah. Sehingga akan terlihat perubahan deformasi di wilayah DKI Jakarta. Keakuratan penurunan tanah tidak divalidasi di lapangan, tetapi diverifikasi terhadap hasil pengukuran dari studi sebelumnya di daerah penelitian DKI Jakarta.

\section{F. Prosedur Penelitian}

Data-data yang diperoleh kemudian dipasangkan masing-masing mempunyai data master dan slave sendiri. Artinya dalam satu pasang terdapat dua data satelit. Halyang perlu diperhatikan dalam menentukan pasangan satelit adalah pastikan estimasi jarak utama (baseline perpendicular) master dan slave tidak begitu besar untuk menghindari koherensi antardata yang buruk. Informasi ini dapat dilihat pada menu InSAR Stack Overview di perangkat lunak SNAP.

Proses seterusnya di perangkat lunak SNAP antara lain adalah koregistrasi citra untuk menyatukan antar piksel master dan slave. Citra yang didapatkan memiliki tiga sub-swath (IW1, IW2, dan IW3). Setiap sub-swath terdiri dari 9-10 burst. Pada penelitian ini wilayah DKI Jakarta berada di IW2 dan dipilih 3 burst pada masing-masing pasangan citra. Pemilihan sub-swath dan burst dilakukan sesuai dengan daerah penelitian. Dalam tahap ini juga dilakukan proses koreksi orbit dengan Sentinel Precise dan tahapan back-geocoding dengan DEM SRTM $3 \mathrm{sec}$ dengan resolusi 30 meter yang diunduh secara otomatis dan menggunakan metode resampling bilinear interpolation (metode pencitraan untuk meningkatkan ataumengurangi jumlah piksel dalam gambar digital sehingga menghasilkan gambar yang bagus).

Tahapan selanjutnya adalah pebentukan interferogram dan koheren. Semakin kecil nilai koherensi maka semakin rendah tingkat kecocokan antar citra tersebut (Hartl, 1996). Apabila nilai koherensi sudah lebih dari 0,2 maka dapat dilanjutkan ke tahap berikutnya. Namun, rata-rata nilai koherensi yang sering didapatkan adalah sekitar 0,3 sehingga dapat langsung dikerjakan pada proses TOPSAR Deburst, dimana tahap ini melakukan penggabungan ketiga burst yang terpisah dengan garis hitam antar burst

Supaya pengolahan yang dilakukan lebih terfokus kepada daerah penelitian yang diinginkan, yaitu DKI Jakarta, maka Subset dapat dipilih sebagai langkah seletah 
TOPSAR Deburst. Pemfokusan daerah penelitian ini juga baik untuk mengurangi lama proses running perangkat lunak. Kemudian dilakukan penghapusan fasa topografi, dimana tahap ini membuat simulasi interferogram berdasarkan referensi DEM dan men-substraksikan fasa topografi dari interferogram yang diolah. DEM yang digunakan pada tahapan ini adalah DEM SRTM 3 sec yang terunduh otomatis dalam perangkat lunak SNAP.

Dalam pembuatan interferogram selanjutnya, dilakukan teknik filtering yang berfungsi untuk mereduksi fasa noise, yakni Goldstein Filtering menggunakan setelan tetap (default) dari fitur SNAP. Setelah di filter, langkah berikutnya dilakukan Multilooking yang berfungsi untuk mengurangi fasa noise pada citra SAR dengan membentuk piksel mendekati bujur sangkar. Namun, fasa-fasa yang sudah terbentuk dalam pemprosesan sampai Multilooking masih mengandung fasa ambiguitas, sehingga perlu dihilangkan fasa ambiguitas tersebut menjadi fasa absolut. Proses ini disebut Phase Unwrapping yang dikerjakan dalam perangkat lunak SNAPHU bersistem operasi Linux. Sebelumnya, untuk memasuki proses ke SNAPHU, hasil tahapan multilooking perlu di ekspor unwrap dalam perangkat lunak SNAP. Setelah proses di SNAPHU selesai, dapat dikerjakan lagi menggunakan SNAP dengan setelan impor unwrap.

Prosedur selanjutnya dilakukan konversi data unwrap menjadi fasa ke tinggi untuk mengetahui perbedaan tinggi dari proses DInSAR atau mengonversi dari slant to height dengan menggunakan Phase to Displacement di perangkat lunakSNAP. Langkah selanjutnya adalah geocoding, yakni dalam SNAP disebut RangeDoppler Terrain Correction. Hasil geocoding ini yang digunakan selanjutnyauntuk membuat peta spasial penurunan muka tanah.

\section{Hasil dan Pembahasan}

\section{A. Hasil Pengolahan Penurunan Muka Tanah DKI Jakarta Tahun 2016}

Hasil dari pengolahan DInSAR pada penelitian tahun 2016 dapat dilihat pada Gambar 4.1, dimana penurunan muka tanah di DKI Jakarta tahun 2016 dibagi dalam kelas warna yakni merah, kuning, dan hijau. Warna hijau menunjukkan rentang adanya penurunan muka tanah sebesar $0--7,33 \mathrm{~cm} /$ tahun. Warna kuning menunjukkan rentang penurunan muka tanah sebesar -7,33--14,67 cm/tahun dan warna merah menunjukkan penurunan muka tanah yang paling tinggi dengan rentang nilainya sebesar $-14,67--22 \mathrm{~cm} /$ tahun.

Berdasarkan peta penurunan muka tanah DKI Jakarta tahun 2016 yang ditampilkan pada Gambar 3, secara keseluruhan penurunan muka tanah di tahun 2016 terjadi di seluruh wilayah DKI Jakarta (warna kuning) dengan memiliki nilai yang bervariasi dan rata-rata penurunannya adalah $-12,5583418(\sim-12,6)$ $\mathrm{cm} /$ tahun. Adapun penurunan tanah warna merah lebih banyak muncul di wilayah Jakarta Utara bagian Timur dan sebagian kecil di wilayah dekat Teluk Jakarta. Ramadhanis (2017) menuliskan bahwa daerah bagian Timur wilayah Jakarta Utara berupa bukan kawasan terbangun, seperti: lahan pertanian dan peternakan, lahan kosong, hutan bakau, dan lain sebagainya. 


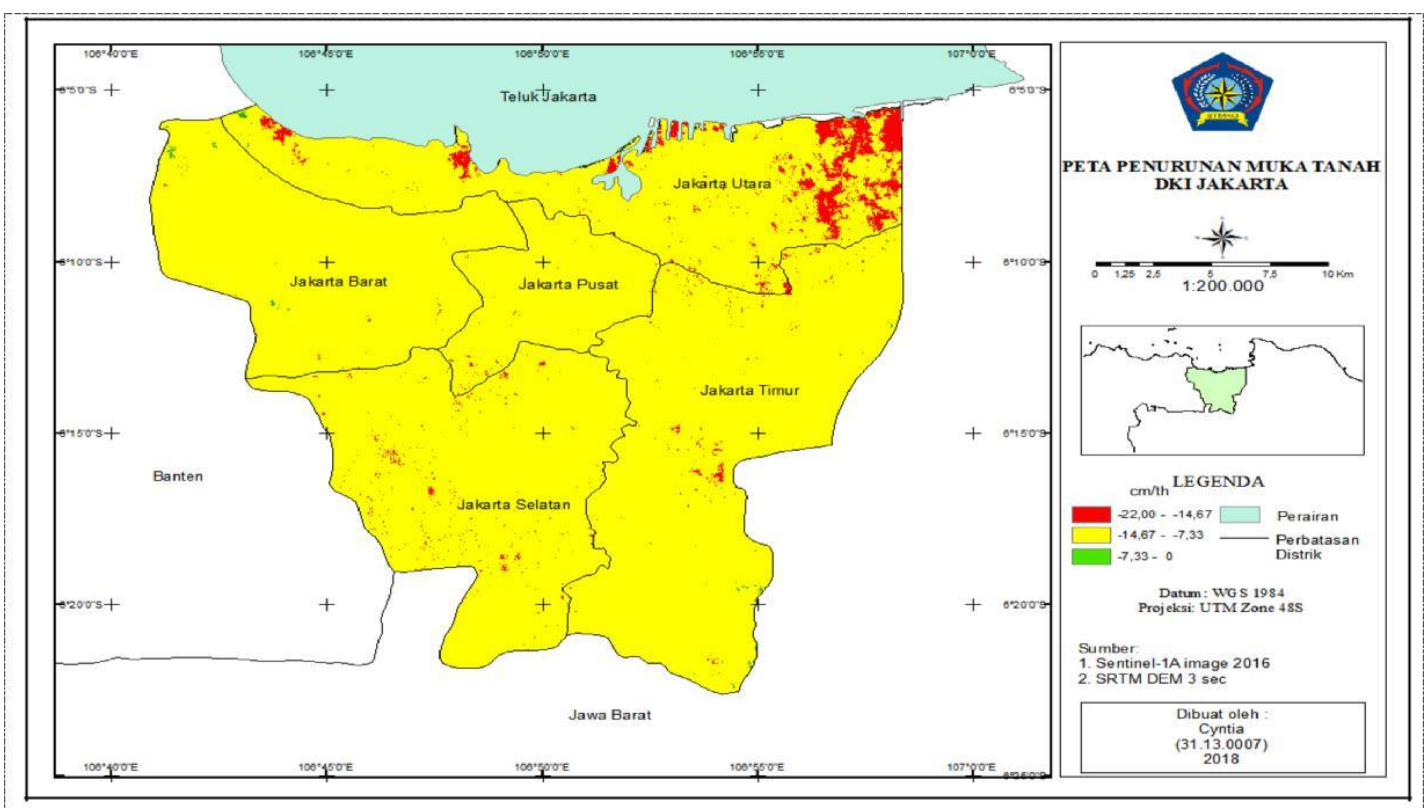

Gambar 3. Peta penurunan muka tanah DKI Jakarta tahun 2016

Tabel 5. Nilai Penurunan Muka Tanah DKI Jakarta di Tahun 2016 dengan Metode DInSAR

\begin{tabular}{llrr}
\hline \multicolumn{1}{c}{ Wilayah } & \multicolumn{1}{c}{$\begin{array}{c}\text { Maksimum } \\
(\mathbf{c m} / \mathbf{t h})\end{array}$} & $\begin{array}{c}\text { Minimum } \\
(\mathbf{c m} / \mathbf{t h})\end{array}$ & Rata-Rata (cm/th) \\
\hline DKI Jakarta (Provinsi) & $-21,9985575$ & 0 & $-12,5583418$ \\
Jakarta Barat & $-17,0829862$ & $-3,4615424$ & $-11,7355387$ \\
Jakarta Pusat & $-16,9627756$ & $-8,9130834$ & $-13,0538497$ \\
Jakarta Utara & $-21,9985575$ & 0 & $-12,9719867$ \\
Jakarta Timur & $-19,9509129$ & $-3,6338978$ & $-12,1479308$ \\
Jakarta Selatan & $-17,7513048$ & $-7,7574022$ & $-13,1615789$ \\
\hline
\end{tabular}

Tabel 5. menunjukkan bahwa penurunan muka tanah tertinggi terjadi di Jakarta Utara dengan nilai maksimum -21,9985575 ( -22) $\mathrm{cm} /$ tahun dengan nilai ratarata penurunan muka tanah sebesar -12,9719867 ( -13) cm/tahun, sedangkan penurunan muka tanah terendah terjadi di Jakarta Pusat dengan nilai maksimum $16,9627756(\sim-17) \mathrm{cm} /$ tahun dengan nilai rata-rata penurunan muka tanah sebesar $-13,0538497(\sim-13) \mathrm{cm} / \mathrm{tahun}$.

\section{B. Hasil Pengolahan Penurunan Muka Tanah DKI Jakarta Tahun 2017}

Hasil dari pengolahan DInSAR pada penelitian tahun 2017 dapat dilihat pada Gambar 4, dimana penurunan muka tanah di DKI Jakarta tahun 2017 dibagi dalam kelas warna yakni merah, kuning, dan hijau. Warna hijau menunjukkan rentang adanya kenaikan muka tanah sebesar $0,40-7,60 \mathrm{~cm} /$ tahun. Warna kuning menunjukkan adanya rentang penurunan muka tanah sebesar 0,40 - -6,80 $\mathrm{cm} /$ tahun dan warna merah menunjukkan penurunan muka tanah yang paling tinggi dengan rentang nilainya sebesar $-6,80--13,99 \mathrm{~cm} /$ tahun.

Nilai penurunan tanah rata-rata DKI Jakarta tahun 2017 adalah sebesar $1,828905312(\sim-1,8) \mathrm{cm} /$ tahun seperti yang ditunjukkan Tabel 4.3 bahwa penurunan tanah tertinggi terjadi di wilayah Jakarta Utara dengan nilai maksimum 
$-13,99370432(\sim-14) \mathrm{cm} /$ tahun dengan nilai rata-rata penurunan muka tanah sebesar -3,468365015 $(\sim-3,5) \mathrm{cm} /$ tahun, sedangkan penurunan tanah tanah terendah terjadi di Jakarta Pusat dengan nilai maksimum -7,207098603 ( -7) $\mathrm{cm} /$ tahun dengan nilai rata-rata penurunan muka tanah sebesar $-0,748964801(\sim$ 1) $\mathrm{cm} /$ tahun.

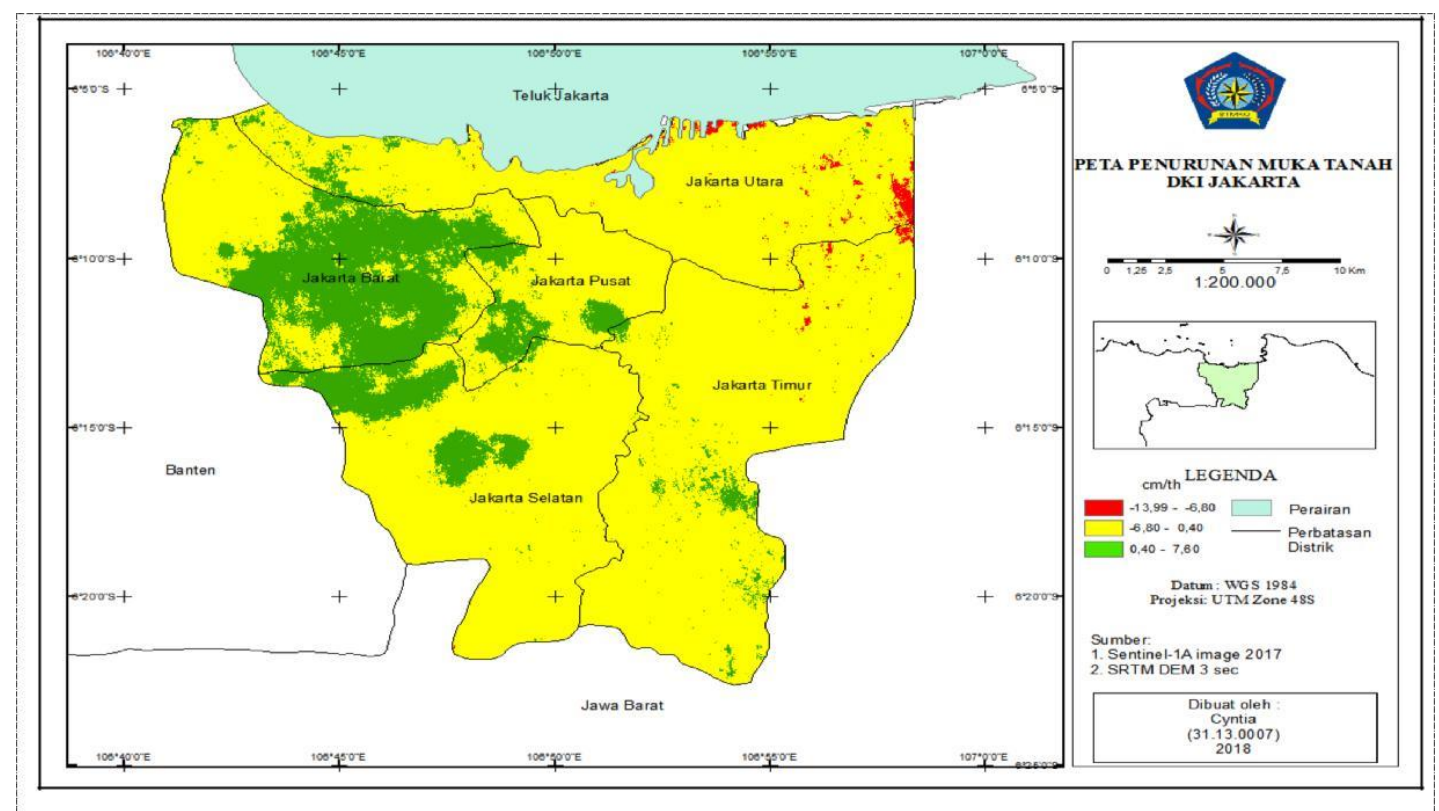

Gambar 4. Peta penurunan muka tanah DKI Jakarta tahun 2017

C. Analisis dan Perbandingan Hasil Penurunan Muka Tanah DKI Jakarta Tahun $2016-2017$

Secara menyeluruh DKI Jakarta tahun 2016 mengalami penurunan muka tanah (PMT) dengan nilai PMT cukup signifikan yakni rata-rata $-12,6 \mathrm{~cm} / \mathrm{tahun}$ dan nilai PMT maksimum mencapai $-22 \mathrm{~cm} /$ tahun di wilayah Jakarta Utara. Hal ini diperkirakan ada kaitannya dengan peristiwa El Nino tahun 2015, keadaan memanasnya suhu permukaan laut di Ekuator Pasifik, berpengaruh terhadap pengurangan curah hujan secara drastis. Akibatnya air tanah berkurang cukup besar dan seperti yang dikertahui bahwa kebanyakan rata-rata penduduk DKI Jakarta memanfaatkan air tanah sebagai sumber pokok, serta ditambah pembebanan bangunan di atasnya yang membuat semakin parah.

Apabila melihat kejadian PMT di tahun berikutnya yakni PMT tahun 2017, keadaan PMT berubah tidak mengalami penurunan sebesar tahun 2016, yakni rata-rata $-1,8 \mathrm{~cm} /$ tahun dengan nilai PMT maksimum $-14 \mathrm{~cm} /$ tahun terjadi di wilayah yang sama, wilayah Jakarta Utara. Namun, selain perbedaan nilai PMT yang cukup drastis, adanya kenaikan di sebagian besar wilayah Jakarta Barat, dan beberapa bagian di Jakarta Utara, Jakarta Pusat, Jakarta Selatan, dan Jakarta Timur. Hal ini diperkirakan karena adanya curah hujan tinggi di tahun 2017 sehingga permukaan tanah mengalami kenaikan (uplift). Sumber media digital Kompas (2017) dalam tulisannya menyebutkan bahwa pada bulan Februari 2017 terdapat hujan deras yang mengakibatkan banjir di 54 titik di DKI Jakarta. Hal ini 
diperjelas oleh BNPB wilayah yang terkena genangan banjir meliputi Jakarta Selatan (11 titik), Jakarta Timur (29 titik), dan Jakarta Utara (14 titik). Kemudian terdapat curah hujan tinggi pula pada bulan Desember 2017 yang menyebabkan beberapa wilayah di DKI Jakarta tergenang banjir.

Tabel 6. memperlihatkan rata-rata penurunan muka tanah dalam kurun waktu penelitian tahun 2016 hingga 2017. Didapatkan rata-rata PMT di DKI Jakarta dalam periode tersebut adalah sebesar $-7,2 \mathrm{~cm} /$ tahun. Jakarta Utara memiliki ratarata PMT terbesar diantara wilayah lainnya yakni sebesar $-8,2 \mathrm{~cm} /$ tahun. Sedangkan Jakarta Barat mengalami PMT terendah dengan nilai rata-rata $-5,7$ $\mathrm{cm} /$ tahun. Penurunan ini diakibatkan oleh beberapa faktor utama, yakni faktor geologi yang utamanya adalah aluvial yang mudah terdeformasi, adanya pembebanan massa bangunan, dan pengambilan air tanah. Minardi dkk. (2014) menuliskan PMT akibat pengambilan air tanah mempunai nilai yang tergradasi dimana semakin ke Selatan amblesan didominasi oleh sumber tersebut. Sedangkan PMT akibat pembebanan di permukaan terbesar terjadi di Jakarta Barat dan Jakarta Utara.

Tabel 6. Penurunan Muka Tanah Tahun 2016 hingga 2017

\begin{tabular}{lccc}
\hline \multicolumn{1}{c}{ Wilayah } & $\mathbf{2 0 1 6}(\mathbf{c m} / \mathbf{t h})$ & $\mathbf{2 0 1 7}(\mathbf{c m} / \mathbf{t h})$ & Rata-rata $(\mathbf{c m} / \mathbf{t h})$ \\
\hline DKI Jakarta (Provinsi) & $-12,6$ & $-1,8$ & $-7,2$ \\
Jakarta Barat & $-11,7$ & 0,3 & $-5,7$ \\
Jakarta Pusat & $-13,1$ & $-0,7$ & $-6,9$ \\
Jakarta Utara & $-13,0$ & $-3,5$ & $-8,2$ \\
Jakarta Timur & $-12,1$ & $-2,6$ & $-7,4$ \\
Jakarta Selatan & $-13,2$ & $-1,4$ & $-7,3$ \\
\hline
\end{tabular}

D. Validasi

Validasi dilakukan untuk mengetahui hasil yang diperoleh dari metode DInSAR jika dibandingkan dengan hasil penelitian mengenai penurunan muka tanah yang sudah pernah dilakukan di DKI Jakarta. Berikut perbandingannya dikaji dalam Tabel 7.

Tabel 7 dan Gambar 5 menunjukkan hasil PMT dengan metode GPS periode penelitian dari 1997 - 2005 oleh Abidin dkk. (2007), metode Gayaberat Mikro dan Gradien Vertikal Antar Waktu periode penelitian 2008 - 2009 oleh Minardi dkk. (2014), dan metode DInSAR periode penelitian 2016 - 2017, terdapat perbedaan antar hasil penelitian, tetapi apabila dirata-ratakan maka kesesuaiannya tidak begitu jauh. Perbedaan hasil disebabkan beberapa faktor, antara lain pengambilan air tanah berlebihan, intrusi air tanah, beban bangunan, struktur geologi aluvial, dan lainnya. 
Tabel 7. Perbandingan Hasil Penurunan Muka Tanah DKI Jakarta dari beberapa Metode Penelitian

\begin{tabular}{lccccccc} 
& \multicolumn{3}{c}{ GPS (cm/th) } & & $\begin{array}{c}\text { Gayaberat } \\
\text { Mikro } \\
\end{array}$ & \multicolumn{1}{c}{ (cm/th) } & $\begin{array}{c}\text { DInSAR } \\
(\mathbf{c m} / \mathbf{t h})\end{array}$ \\
\cline { 2 - 8 } & $\mathbf{1 9 9 7 -}$ & $\mathbf{1 9 9 9 -}$ & $\mathbf{2 0 0 0 -}$ & $\mathbf{2 0 0 1 -}$ & $\mathbf{2 0 0 2 -}$ & $\mathbf{2 0 0 8 - 2 0 0 9}$ & $\mathbf{2 0 1 6 - 2 0 1 7}$ \\
\hline JakBar* & $-0,8$ & $-1,2$ & $-2,8$ & $-6,6$ & $-10,8$ & $-8--13$ & $-5,7$ \\
JakPus* & $-3,8$ & $-1,1$ & $-0,8$ & $-4,5$ & $-10,8$ & $<-8$ & $-6,9$ \\
JakUt* & $-0,8$ & $-0,5$ & $-5,3$ & $-9,2$ & $-12,5$ & $-8--13$ & $-8,2$ \\
JakTim* & -- & -- & $-1,5$ & $-5,9$ & $-5,5$ & $<-8$ & $-7,4$ \\
JakSel* & $-4,6$ & $-2,4$ & $-4,2$ & --- & $-6,9$ & $<-8$ & $-7,3$ \\
\hline
\end{tabular}

\section{Keterangan:}

*Lokasi sampling penelitian GPS, dari Jakbar-Jaksel (sesuai tabel): Tomang, Kwitang, Mutiara,

Cipinang, dan Kebayoran.

--- : tidak ada data

Wilayah Jakarta Utara memiliki penurunan muka tanah terbesar selama interval waktu antara 2016 dan 2017, walaupun wilayah ini memiliki populasi yang lebih sedikit jika dibandingkan dengan wilayah administrasi lainnya. Namun, lahan di Jakarta Utara banyak digunakan sebagai kawasan industri, area reklamasi, pelabuhan dan lainnya. Sementara lahan di Jakarta Barat dikembangkan untuk pembangunan apartemen/rumah susun, dan kawasan industri serta bandara internasional dibangun di dekatnya. Di Jakarta Pusat, Jakarta Timur, Jakarta Selatan utamanya lahan dikembangkan sebagai daerah pemukiman, kawasan perkantoran dan perbelanjaan, dimana juga banyak gedung tinggi sehingga beban permukaan tanah semakin besar.

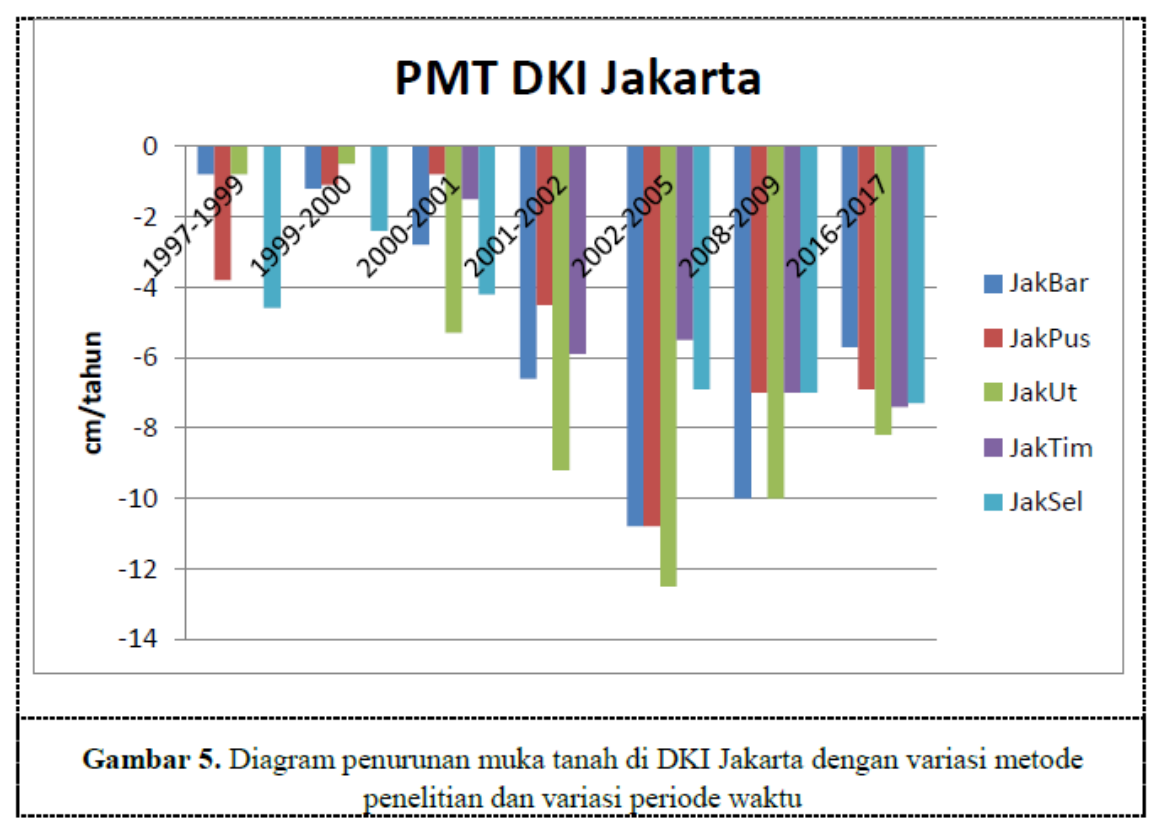




\section{Kesimpulan}

Penurunan muka tanah DKI Jakarta dengan metode Differential Interferometric Synthetic Aperture Radar (DInSAR) dapat dihitung. Secara keseluruhan wilayah DKI Jakarta mengalami penurunan muka tanah. Wilayah Jakarta Utara memiliki penurunan muka tanah terbesar selama interval waktu antara 2016 dan 2017. Dalam interval waktu dari 2016 - 2017 penurunan muka tanah di DKI Jakarta rata-rata sebesar -7,2 cm/tahun. Wilayah administrasi Jakarta Barat -5,7 $\mathrm{cm} /$ tahun, Jakarta Pusat $\sim-6,9 \mathrm{~cm} /$ tahun, Jakarta Utara $\sim-8,2 \mathrm{~cm} /$ tahun, Jakarta Timur $\sim-7,4 \mathrm{~cm} /$ tahun, dan Jakarta Selatan $\sim-7,3 \mathrm{~cm} / \mathrm{tahun}$.

Hasil penelitian dengan metode DInSAR jika dibandingkan dengan hasil penelitian yang telah dilakukan sebelum tahun 2017 menunjukkan hasil yang bersesuaian terhadap penelitian yang telah dilakukan dengan metode Global Positioning System (GPS) dan metode Gayaberat Mikro dan Gradien Vertikal Antar Waktu untuk cakupan wilayah yang luas. Kemampuan ini berguna untuk mendukung kegiatan tata kota dan perencanaan yang akan dilakukan selanjutnya.

\section{Ucapan terima kasih}

Penulis ingin mengucapkan terima kasih kepada program EU Copernicus yang dapat menyediakan data satelit radar Sentinel-1A. Kami juga ingin menunjukkan rasa terima kasih kami kepada Zainab Ramadhan dan orang-orang di Forum ESA untuk berbagi mutiara kebijaksanaan mereka dengan kami selama penelitian ini, dan kami berterima kasih kepada orang-orang yang selalu bersedia memberi dukungannya.

\section{Daftar Pustaka}

1. Badan Pusat Statistik (BPS), Data Statistik Provinsi DKI Jakarta, Tersedia pada: https://jakarta.bps.go.id, 2015.

2. D. Murdohardono, U. Sudarsono, Land subsidence monitoring system in Jakarta, Proceedings of Symposium on Japan-Indonesia IDNDR Project: Volcanology, Tectonics, Flood and Sediment Hazards, Bandung, 21-23 September (1998) p. 243-256.

3. P. W. Francis, G. Wadge, and P.J. Mouginis-Mark, Satellite monitoring of volcanoes, Dalam R. Scarpa and R.I. Tilling (eds.) Monitoring and mitigation of volcano hazards, Springer-Verlag: New York (1996) p. 257-298.

4. ESA, Part A InSAR Processing: Guidelines for SAR Interferometry Processing and Interpretation (Tutorial), ESA Publications, ESTEC, Netherlands, 2007.

5. ESA, Part B InSAR Processing: A Partical Apprcoach (Tutorial). ESA Publications, ESTEC, Netherlands, 2007.

6. ESA, Part C InSAR Processing: A Mathematicall Apprcoach (Tutorial) ESA Publications. ESTEC, Netherlands, 2007.

7. ESA, "What is Sentinel-1?", Available: https://earth.esa.int/ web/guest/missions/esa-operational-eo-missions/sentinel-1, 2015.

8. H. Z. Abidin, H., Andreas, R. Djaja, D. Darmawan, dan M. Gamal, Land Subsidence Characteristics of Jakarta between 1997 and 2005, as Estimated Using GPS Surveys, GPS Solutions (12) 1: 23-32, Springer 
Berlin/Heidelberg, DOI: 10.1007/s10291-007-0061-0, Website: http://dx.doi.org/10.1007/s10291-007-0061-0, 2007.

9. Kompas, Hujan Deras, 54 Titik di Jakarta Terendam Banjir. Tersedia pada: https://megapolitan.kompas.com/read/2017/02/21/09235601/hujan.deras.54.ti tik.di.jakarta.terendam.banjir, 2017.

10. L.L.B. Chavez, P. Richard, K. Riordan, N. Miller, and H. Barada, Improving wetland characterization with multi-sensor, multi-temporal SAR and optical/infrared data fusion, 2009.

11. S. Minardi, Hiden, Daharta Dahrin, Mahmud Yusuf, Analisa Penurunan Airtanah dan Amblesan Tanah dengan Metode Gayaberat Mikro dan Gradien Vertikal Antar Waktu: Studi Kasus di Jakarta. Jurnal Ilmu Dasar, Vol. 15 No. 1 (2014).

12. T. O. Akbar, Yudo Prasetyo, Arwan Putra W., Analisis Dampak Penurunan Muka Tanah Terhadap Tingkat Ekonomi Menggunakan Kombinasi Metode DInSAR dan SIG (Studi Kasus: Kota Semarang), Jurnal UNDIP, Vol. 4 No. 4 (2015).

13. Z. Ramadhanis, Y. Prasetyo, B. D. Yuwono, Analisis Korelasi Spasial Dampak Penurunan Muka Tanah Terhadap Banjir di Jakarta, Jurnal Geodesi UNDIP Vol. 6 No. 3 (2017). 